\title{
Empowered or engaged employees? A fuzzy set analysis on knowledge transfer professionals
}

\section{Valentina Cucino, Nicola Del Sarto, Alberto Di Minin and Andrea Piccaluga}

\begin{abstract}
Purpose - This paper combines the literature on knowledge transfer and that on organizational behavior to analyze how perceived empowerment and perceived engagement affect knowledge transfer offices' (KTOs') performance, measured in terms of the number of license agreements.

Design/methodology/approach - The authors measured the cognitions which constitute perceived empowerment and perceived engagement through a survey sent to Italian KTOs' professionals. The authors performed "fuzzy set qualitative analysis" to investigate if this cognition, together or in isolation, may influence KTOs' management performance, measured by the number of license agreements.

Findings - The results highlight the role of individual cognitions in influencing KTOs' performance. Furthermore, an important finding from the analysis of the main configurations is that the co-presence of perceived engagement and perceived empowerment leads to more license agreements only in the presence of specific individual cognitions. More precisely, the level of organizational citizenship behavior, the degree to which an individual influences results at work (degree of impact) and the value of a work goal (degree of meaning) are the cognitions which lead to a higher number of license agreements.

Originality/value - Despite the growing interest in the investigation of the determinants of KTOs' performance, a relevant research gap still concerns the explanation of KTOs' performance considering individual cognitions such as attitudes, norms, perceived behavioral control and intentions. This study looks at the combined effect of the individual cognition of perceived engagement and perceived empowerment on KTOs' performances.
\end{abstract}

Keywords fSQCA, Knowledge transfer offices, Knowledge transfer professionals, Perceived empowerment, Perceived engagement

Paper type Research paper

\section{Introduction}

The relevance of knowledge transfer from university to industry is widely recognized as an important area of knowledge management (Bekkers and Freitas, 2008; Goh, 2002; Grimpe and Hussinger, 2013; Kumar and Ganesh, 2009; Santoro and Bierly, 2006). Knowledge transfer offices (KTOs) are organizational units that support the activities of a university or a public research center (Romano et al., 2014) and are involved not only in consolidated tasks such as invention disclosure, patenting, licensing, support to entrepreneurship, etc. (Carlsson and Fridh, 2002; Wolson, 2007) but also in the so called "third mission" activities, aiming to generate positive socio-economic impact on society (Cesaroni and Piccaluga, 2016). These offices have been named in many different ways in the literature - technology transfer offices (TTOs), industrial liaison offices, offices of technology licensing and university TTOs (Brescia et al., 2016; Campbell et al., 2020) but in this paper we will only use the term KTOs, as their activities do not differ significantly in relation to the definition used.
Valentina Cucino, Nicola Del Sarto, Alberto Di Minin and Andrea Piccaluga are all based at the Institute of Management, Scuola Superiore Sant'Anna, Pisa, Italy.

Received 29 May 2020 Revised 26 August 2020 Accepted 28 August 2020

The authors thank the Netval association and Italian technology transfer professionals for allowing this study. The authors extend their sincere thanks to Professors Gretchen Spreitzer and Emma Soane for providing very useful feedbacks to a previous version of the present study and Dr Giulio Ferrigno for providing interesting methodological suggestions. 
An abundant literature states that KTOs perform a prominent role in the knowledge transfer process (Bigliardi et al., 2015; Romano et al., 2014; Sellenthin, 2009; Fai et al., 2018), as they encourage and support relations between industry and university (Algieri et al., 2013; Baines and Lawton Smith, 2020; Fernández-López et al., 2018; Grimpe and Hussinger, 2013). For this reason, many scholars have investigated the main drivers influencing KTOs' performance, which seems to depend on the organizational elements, among which the quantity and quality of the personnel employed (Phan and Siegel, 2006; Shane and Stuart, 2002). Within this vein, several authors have focused on organizational issues, exploring KTOs' organizational structures and linking them to performance (Bercovitz et al., 2001; Siegel et al., 2003; Lafuente and Berbegal-Mirabent, 2019). Siegel et al. (2003) showed that the main organizational elements which influence KTO productivity are departments' incentive systems, the presence of employees with a management background and the absence of cultural walls around research organizations. Chapple et al. (2005) also observed that KTOs' effectiveness is connected to the quality of the department, the specialization on specific subjects and the existence of a school of medicine or an academic hospital. Bercovitz and Feldman (2008) highlighted the consequences of the various KTO organizational systems regarding the ability to coordinate incentives. However, despite the growing interest in the investigation of the determinants of KTOs' performance (Chapple et al., 2005; Lafuente and Berbegal-Mirabent, 2019; Siegel et al., 2007), a relevant research gap still concerns the explanation of KTOs' performance considering individual cognitions such as attitudes, norms, perceived behavioral control and intentions.

Individual cognitions translate into behaviors which play a significant role in organizations, particularly when decisions have to be taken (Gioia and Manz, 1985; Gregory et al., 2010). Such individual cognitions have been recognized as crucial for the performance of employees within organizations (Soane et al., 2012; Spreitzer, 1995; Hao et al., 2018), but previous scholars have neglected to investigate them as a driver for KTOs' performance. To fill this gap, we explore the following research question: "Is there a relationship between the interaction of individual cognitions of perceived empowerment and perceived engagement and KTOs' performance?"

For our research objective, we draw from the microfoundation literature (Felin and Hesterly, 2007; Felin and Foss, 2005; Abell et al., 2008) and analyze the individual level of knowledge transfer, given its importance to understand how and why knowledge emerges from employees and circulates within organizations and how individuals' characteristics, skills, proclivities, movements, expectations and behaviours (Felin and Foss, 2005) have an impact on organizations' performances (Inés Macho-Stadler et al., 2007; Owen-Smith, 2011). Furthermore, we draw from the literature about perceived organizational support, from which we identified two individual cognitions influencing organizations performance: perceived empowerment (Spreitzer, 1995) and perceived engagement (Soane et al., 2012). In particular, we measured the cognitions which constitute perceived empowerment and perceived engagement through a survey sent to all Italian KTOs' professionals knowledge transfer professionals (KTPS). KTPs are the intermediaries between technology providers and external organizations that refer to KTOs (Colcelli, 2019), and their role is certainly important within KTOs (Volberda et al., 2012; DeVol et al., 2006). We used "fuzzy-set qualitative comparative analysis" (fsQCA) (Ragin and Beck, 1987), together or in isolation, with KTOs' performance, measured by the number of license agreements. Our analysis focuses on Italian KTOs, as they represent a relevant context for analyzing organizational behaviors, where perceived empowerment and perceived engagement are very indicative. Indeed, KTOs are part of the organization of universities and are not independent profit centers (Romano et al., 2014), for this reason, KTOs and KTPs depend on the universities that delegate roles and responsibilities. The use of fsQCA is suited for this study, as it allows us to investigate the combinations of conditions and their relations with an outcome of interest (Cabrilo and Dahms, 2018; Del Sarto et al., 2020; Lowik et al., 2016). 
The study demonstrates the role of individual cognitions in influencing KTOs' performance and contributes to the literature about KTOs' performance in three different ways. First, it points out that none of the individual cognitions of perceived empowerment and perceived engagement influences KTOs performance in isolation. Second, it identifies which combinations of individual cognitions are related to a KTO's performance. Third, it highlights that the lack of willingness of knowledge transfer professionals to change their jobs increases the performance of KTOs.

The paper is organized as follows. Section 2 explains the role of KTPs in KTOs, the importance of perceived organizational support in influencing organizations' performance and the definition of perceived empowerment and perceived engagement. Section 3 reports the method and the fsQCA. Section 4 describes our findings. Section 5 includes the conclusion, including limits and future research.

\section{Theoretical background}

\section{1 Importance of perceived organizational support in influencing organizations' performance}

The individual abilities of KTPs are fundamental for knowledge transfer activities (Markman et al., 2005; Harman and Stone, 2006; Volberda et al., 2012; Cunningham et al., 2020). First, knowledge transfer professionals participate in the construction of innovation, as they contribute to "imagine" the final product in its "usage context" (Miller et al., 2009). Second, they contribute to a dynamic relationship with industry, and they evaluate inventions together with the inventors to manage disclosure and patenting processes (Sandelin, 2003; Cunningham et al., 2020). Third, their role is indispensable to establish a relation of mutual confidence with the licensee (Amidon, 1996; DeGeeter, 2004). As a matter of fact, several authors have studied the role of KTPs in KTOs. Markman et al. (2005) and Mom et al. (2012) focused on competencies and skills, Lockett and Wright (2005) focused on capabilities, and Hülsbeck et al. (2013) focused on the division of labor. Alessandrini et al. (2013) also emphasized the importance of KTPs in KTOs. Ghoshal and Bartlett (1994) argued that the creation of a positive organizational context plays a role in determining KTOs' performance. Although several authors have also investigated organizational issues (Bercovitz et al., 2001), there is still a need for research in this field and relevant gaps exist. For example, no authors have investigated the motivations or the cognitions of individuals to explain KTOs' productivity.

The literature about perceived organizational support may help explain employees' commitment to their organization (Rhoades et al., 2001; Zhong et al., 2016; Byrne and Hochwarter, 2008; Shanock and Eisenberger, 2006). Indeed, such literature assumes that there is a potential relationship between individual cognition of employees and organizational performance (Jenkins and Johnson, 1997; Wang, 2011). Perceived organizational support may be influenced by various aspects of an employee's management by the organization and would, in turn, influence the employee's interpretation and organizational behavior (Eisenberger et al., 1986; Eisenberger et al., 2002; Shanock and Eisenberger, 2006; Byrne and Hochwarter, 2008).

Furthermore, the perceived organizational support emphasizes that different individual cognitions produce different attitudes and behaviors that affect organizational performance (Rhoades et al., 2001; Luthans et al., 2008, 2007). In particular, trust (Whitener, 2001), organizational commitment (Allen et al., 2003) and organizational citizenship behaviors (Organ and Ryan, 1995; Singh and Singh, 2019) positively influence the employees' behavior toward the organization. Also, self-efficacy and equity have been the objects of a great amount of behavioral research (Luthans et al., 2007). In particular, self-efficacy has been studied by several authors, especially with regard to individual cognition that influences the ability to achieve the desired goals (Bandura, 1986; Luthans et al., 2008; 
Bandura, 2007); equity has been studied by scholars that have examined relationships between perceptions of equity and job satisfaction, turnover (Dittrich and Carrell, 1979; Saks et al., 1995) and organizational attractiveness (Walker et al., 2007). Furthermore, several individual cognitions such as optimism (Luthans et al., 2008), humility (Owens et al., 2013) and empathy (Clark et al., 2019; Chong et al., 2020) have garnered significant attention because of the development in the field of positive psychology and perceived organizational support (Cameron and Caza, 2002; Luthans, 2002; Von Krogh, 1998; Von Krogh et al., 2000; Morris et al., 2005).

Among several studies about perceived organizational support, two cognitions have received particular attention with regard to the links between employees' motivations and performance: perceived empowerment (Fernandez and Moldogaziev, 2013; Spreitzer et al., 1999; Conger and Kanungo, 1988; Cole, 1995; Seibert et al., 2004) and perceived engagement (Macey and Schneider, 2008; Truss et al., 2013; Markos and Sridevi, 2010; Gruman and Saks, 2011). In this study, we focus on perceived empowerment and engagement because unlike other individual cognitions they are broader and include different aspects. In fact, perceived empowerment (Spreitzer, 1995; Spreitzer et al., 1999) is made up of four individual cognitions (meaning, competence, self-determination and impact) while perceived engagement (Soane et al., 2012) is composed of three individual cognitions (task performance, organizational citizenship behavior and quit).

In particular, several authors argue that high employee performance is positively related to perceived empowerment (Fernandez and Moldogaziev, 2011; Kirkman and Benson, 1999; Spreitzer, 1995; Fong and Snape, 2015) and more generally to the intrinsic motivation to the task (Robbins et al., 2002; Conger and Kanungo, 1988; Thomas and Velthouse, 1990). Moreover, empowerment has been defined as a transfer of power or authority (Burke and Day, 1986; Kanter, 1983; Bachouche and Sabri, 2019).

Employee engagement is a desirable condition and connotes involvement, commitment, passion, enthusiasm, concentrated effort and energy (Macey and Schneider, 2008; GonzálezRomá et al., 2006; Lofquist et al., 2017). In particular, when people "can use their favorite self in their work that they experience being involved in that job (state commitment) and also performing to their fullest potential (behavioral commitment)" (Kahn, 1990). Engagement emerges as a function of the interaction between the attributes of the person and the work he/she does (Khan, 1992) and for this reason it is one of the cognitions that most influences performance.

Both empowerment and engagement are related to task motivation and commitment in the workplace and both affect performance; for this reason, these two variables lend themselves to be the most pertinent for our study. Therefore, in this study, we focus on the role of perceived empowerment and perceived engagement in Italian KTOs.

\subsection{Importance of perceived empowerment and engagement in knowledge transfer offices}

Among other factors, KTOs' performance depends on behavioral organizational variables, and we argue that such variables are influenced by the individual cognitions of KTPs such as perceived empowerment (Spreitzer, 1995; Spreitzer et al., 1999) and perceived engagement (Soane et al., 2012). On this basis, we explore how the cognitions of perceived empowerment and perceived engagement affect knowledge transfer performance.

With regard to the combination of perceived empowerment and perceived engagement, a previous study of 607 executives in India shows how the perception of greater empowerment is linked to active engagement (Bhatnagar, 2005). However, only a few other studies investigate the co-presence of the two elements (Saks, 2006; Vigoda-Gadot et al., 2013). Building on this literature, we decided to combine the two concepts with regard to knowledge transfer professionals, and we explored the main configurations of perceived engagement and perceived empowerment on license agreements. 
2.2.1 Perceived empowerment. Several authors argue that high perceived empowerment is positively correlated with employees' performance (Bowen and Lawler, 1992; Chamberlin et al., 2018; Conger and Kanungo, 1988; Fernandez and Moldogaziev, 2011; Kirkman and Benson, 1999). In particular, some studies highlight a favorable link between employee empowerment and company effort (Patterson et al., 2004), organizational commitment (Guthrie, 1998; Kirkman and Benson, 1999; Spreitzer, 2007), employee attitudes (Fernandez and Moldogaziev, 2013), involvement at work (Cotton et al., 1988), leadership (Dust et al., 2014), job satisfaction (Ugboro and Obeng, 2000) and knowledge management (Akbari and Ghaffari, 2017; Yahya and Goh, 2002). Furthermore, some authors argue that perceived empowerment is the mechanism by which employees perceive the organizational support linked to positive behavior in the workplace (Lamm et al., 2015). Other studies highlight the importance of perceived empowerment on organizational commitment, quality of service, job satisfaction and innovative effectiveness and behavior (Bhatnagar, 2005; Joo and Shim, 2010; Seibert et al., 2004).

Perceived empowerment also causes indirect effects. Fernandez and Moldogaziev (2013) highlight how employee empowerment has a direct consequence on performance and an indirect consequence on job satisfaction and innovation. Conger and Kanungo (1988) link perceived empowerment to a motivational construct connected to self-evaluation. However, empowerment is a multi-faceted concept that includes several elements. Spreitzer (1995) and Thomas and Velthouse (1990) have outlined empowerment as "the manifestation of an increased intrinsic motivation within four constructs" that show the attitude of an individual to his/her working role. Following Spreitzer (1995), we define perceived empowerment as a higher motivation of the knowledge transfer professionals to carry out their work (Perceived Empowerment Scale). Mainly, we define perceived empowerment as "a motivational construct expressed in four cognitions: meaning, competence, self-determination and impact" (Spreitzer, 1995). This scale will be used in this study to evaluate employee empowerment (Spreitzer, 1995).

Perceived empowerment scale (Spreitzer, 1995):

1. MEANING:

- The work I do is very important to me (Meaning 1).

- My job activities are personally meaningful to me (Meaning 2).

- The work I do is meaningful to me (Meaning 3).

2. COMPETENCE:

- I am confident about my ability to do my job (Competence 1).

- I am self-assured about my capabilities to perform my work activities (Competence 2).

- I have mastered the skills necessary for my job (Competence 3).

3. SELF-DETERMINATION:

- I have significant autonomy in determining how I do my job (Self-determination 1).

- I can decide on my own how to go about doing my work (Self-determination 2).

- I have considerable opportunities for independence and freedom in how I do my job (Self-determination 3).

4. IMPACT:

- The impact of my work on what happens in my department is significant (Impact 1).

- I have a great deal of control over what happens in my department (Impact 2).

- I have significant influence over what happens in my department (Impact 3). 
The knowledge transfer literature analyses the empowerment phenomenon mainly from the academics' point of view, as in the case of Perkmann et al. (2013), who discuss "academic engagement" in knowledge transfer activities. Instead, in this study, we focus on KTPs. In particular, following Spreitzer (1995), we focus on KTPs' perceptions, and we hypothesize that perceived empowerment is related to license agreements. We hypothesize that every cognition which constitutes the perceived empowerment construct is related to license agreements. In particular, meaning is the significance (in terms of symbolic value) of achieving a job task in relation to the beliefs of the individual (Thomas and Velthouse, 1990) and it is an expression of the relationship between job role and sentiments, values and behaviors (Brief et al., 1995). The result of meaning cognitions is a considerable concentration of energy and a high commitment on the job (Kanter, 1983). As a consequence, the value of the work goal and more generally the knowledge of the value of the work goal influences individual performance in workplace. This leads the way to the first proposition regarding knowledge transfer professionals:

P1. The value of a job task or purpose is related to license agreements.

Competence or self-efficacy is an individual's mental belief about being able to perform specific activities with his/her abilities (Gist, 1987). Competence is an expression of personal mastery (Bandura, 1986), understood as the perceived ability to accomplish workrelated tasks, and it influences individual performance in a managerial context (Morse, 1976). Indeed, there are ample longitudinal and experimental studies supporting the causal influence of self-efficacy (captured by the competence dimension of empowerment) on individual performance in the workplace (Bandura and Locke, 2003; Chen et al., 2007). This leads the way to the second proposition:

$P 2$. The capability to perform activities with abilities is related to license agreements.

Self-determination reflects and how circumstances such as management style and work context support or thwart the individual's motivation and well-being in the workplace (Rigby and Ryan, 2018). Self-determination reflects autonomy in launching and continuing job tasks, such as decisions on approaches, timeline and effort (Spector and Jex, 1998). Selfdetermination supports "work motivation and shows its relevance to organizational behavior" (Gagné and Deci, 2005). In this regard, self-determination influencing motivation, personal goals, wellness in the workplace (Rigby and Ryan, 2018) and, in particular, individual performance in the workplace (Gagné and Deci, 2005; Deci et al., 2017; Ryan and Deci, 2017). This leads the way to the third proposition:

P3. The autonomy launching and continuing of job activities process is related to license agreements.

The fourth dimension of perceived empowerment is impact (Spreitzer, 1995). We define impact as the degree to which a person manages to influence job performance, both operationally and strategically (Ashforth, 1989), and is affected by the working environment (Spreitzer, 1995). Individuals have an influence strategic when the probability of success of their actions is positive (Mowday, 1978) and when the work environment is reactive to their influence attempts. In this way, impact influences individual performance in workplace (Degago, 2014). This leads the way to the fourth proposition:

P4. The degree to which a person manages strategic results at work is related to license agreements.

2.2.2 Perceived engagement. Kahn (1990) identified employees' perceived engagement as "harnessing the self of the members of the organization with respect to their working roles through which they employ and express physically, cognitively and emotionally during the performance of the roles." This description considers perceived engagement as the union between emotional, physical and cognitive energy and work factors. Consequently, according to this definition, the perceived engagement allows employees to direct their 
energies (physical, cognitive and emotional) simultaneously (Kahn, 1990) toward a goal. Perceived engagement has also been defined as "a cognitive, emotional and behavioral state directed towards the desired organizational results" (Shuck and Wollard, 2010).

Engagement literature suggests that employees who perceive more engagement perform better at work (Salanova et al., 2005). Several authors show that perceived engagement is positively linked to the provision of high-quality services (Salanova et al., 2005). Furthermore, better-perceived employee engagement creates a healthy working atmosphere (Anitha, 2014). Halbesleben and Wheeler (2008) showed that engagement generates feelings that improve work performance. Following Kahn (1990) and Soane et al. (2012), we define perceived engagement as a higher involvement of the knowledge transfer professionals in carrying out their work.

Soane et al. (2012) built and implemented a new way to evaluate perceived engagement: the intellectual, social and affective-scale involvement. This scale has been used in this study to evaluate employee engagement. As stated by this scale, perceived engagement is an element made up of three factors (Perceived engagement scale 2): performance of activities (task performance), organizational citizenship behavior (OCB) and intention to quit (quit) (Soane et al., 2012). Building on this literature and following Soane et al. (2012), we focus on the perceptions of knowledge transfer professionals and we hypothesize that the three constructs of perceived engagement are related to licensing agreements.

Perceived engagement scale (Soane et al., 2012):

1. TASK PERFORMANCE:

- I always complete the duties specified in my job description.

- I meet all the formal performance requirements of the job.

- I fulfil all responsibilities required in my job.

- I never neglect aspects of the job that I am obligated to perform.

- I often fail to perform essential duties.

2. ORGANIZATIONAL CITIZENSHIP BEHAVIOR:

- Attend functions that are not required but that help the organizational image.

- Offer ideas to improve the functioning of the organization.

- Take action to protect the organization from potential problems.

- Defend the organization when other employees criticize it.

3. INTENTIONTO QUIT:

- During the next year, I will probably look for a new job outside my current employer.

- I am seriously considering quitting my current employer for an alternative employer.

In particular, task performance is a self-assessment of the performances (Kahn, 1990). Task performance refers to performance on the job that "you were hired to do." This cognition is more likely to benefit the self in terms of career opportunities or bonuses rather than benefit the collective (Van Knippenberg, 2000). Several authors argue that task performance contributed uniquely to overall performance in managerial jobs (Conway, 1999; Sonnentag and Frese, 2002). Indeed, task performance is part of the job requirements, and it affects individual performance in the workplace (Alfes et al., 2013). This leads the way to the fifth proposition:

P5. The self-assessment of the performances is related to license agreements. 
OCB also influences individual (Ehrhart and Naumann, 2004) and organizational performance (Dunlop and Lee, 2004). OCB, the discretionary behavior of employees, going beyond the formal descriptions of the work (Organ, 1988), contributes to positive organizational functioning (Klotz et al., 2018). Indeed, two of the most commonly-cited dimensions of OCB are compliance and altruism (Organ et al., 2006). Moreover, OCB is positively related to both the quality organization's service (Morrison, 1996) and team performance (Lai et al., 2013). Moreover, OCB reflects the strength of the employee's perceived social exchange relationship with the organization (Snape and Redman, 2010). Thus, OCB clearly is relevant for individual performance in the workplace (Snape and Redman, 2010; Zayas-Ortiz et al., 2015). This leads the way to the sixth proposition:

$P 6$. Organizational citizenship behavior is related to license agreements.

Quit is an intention to turnover (Shuck et al., 2014). Dynamic work environments tend to be associated with high levels of emotion and stress (Dane and Brummel, 2014; Klein, 1998). These pressures may become difficult to bear, leading people to consider giving up their employment. According to Hom and Griffeth (1995) and Coyne and Ong (2007), turnover intention is the individual cognition that has been found to have a direct effect on actual turnover. The intention of turnover is subject to a series of influences linked to the characteristics of the work context and to factors at the individual level (Cardador et al., 2011; Meyer et al., 2002). Therefore, even within the same work environment, people's intentions may differ (Dane and Brummel, 2014). A strong organizational identity and a positive organizational climate influence the intention to change jobs and consequently the organizational performance (Cole and Bruch, 2006). As a consequence, the intention to turnover is related to individual performance and OCB (Shore et al., 1990). Indeed, this leads the way to the seventh proposition:

P7. Quit is related to license agreements.

\section{Methodology}

\subsection{Data sources}

We used data from two different sources: the Netval [1] database and a specific survey aimed at Italian university KTPs. The first source provided information on the knowledge transfer activities of Italian universities and research hospitals. Netval annually performs a survey of Italian research organizations to collect data about their knowledge transfer activities. Concerning the second source, a questionnaire [2] was prepared following the work of Spreitzer (1995) and Soane et al. (2012), to measure the perceived empowerment and perceived engagement of Italian KTPs. The questionnaire was first translated in Italian and tested on 10 KTPs. The survey was then conducted between December 2017 and March 2018, addressing all the population of Italian KTPs which, according to Netval (2019), was of 220. After having sent the questionnaire to the whole population, we obtained 187 full questionnaires, with an $85 \%$ response rate considered a good response rate for surveys addressing practitioners (Dillman, 2000). The final sample consists of 77 men and 96 women (14 people have not declared their gender). The average age is 41; 51 people are head of their KTO, and 136 people do not hold full-time positions.

Table 1 shows the descriptive statistics of our sample, which consisted of 63 different research organizations (corresponding to $61 \%$ of Italian KTOs). The average number of KTPs was four. Each KTO spent, on average about $€ 77,000$ in legal fees for external consulting. In 2018, the average number of average licensing agreements was nine.

\subsection{Measurement of variables}

The survey we used for our study was composed of two main sections. The first regards respondents' characteristics, such as age, years of experience in the job and gender. The second section was used to build the constructs of interest on the basis of seven-point 


\begin{tabular}{|c|c|c|c|c|}
\hline Variable name & $\begin{array}{c}\text { Mean } \\
\text { (*Proportion) }\end{array}$ & $S D$ & Min & Max \\
\hline \multicolumn{5}{|l|}{ Individual cognitions } \\
\hline MEANING & 0.60 & 0.20 & 0 & 1 \\
\hline COMPETENCE & 0.57 & 0.18 & 0 & 1 \\
\hline DETERMINATION & 0.54 & 0.18 & 0 & 1 \\
\hline IMPACT & 0.49 & 0.21 & 0 & 1 \\
\hline TASK & 0.48 & 0.23 & 0 & 1 \\
\hline ORG_CITZ & 0.54 & 0.17 & 0 & 1 \\
\hline QUIT & 0.43 & 0.21 & 0 & 1 \\
\hline ENGAGEMENT & 0.57 & 0.18 & 0 & 1 \\
\hline EMPOWERMENT & 0.43 & 0.17 & 0 & 1 \\
\hline \multicolumn{5}{|c|}{ Information about KTO } \\
\hline DIMENSION & 2,555 & 1,803 & 99 & 7,656 \\
\hline LICENSE & 8.8 & 18.8 & 0 & 77 \\
\hline AGE_KTO & 11 & 4.81 & 1 & 19 \\
\hline STAFF_KTO & 4.2 & 3.30 & 0.3 & 15.2 \\
\hline LEGAL & 77,639 & 99,786 & 0 & 436,295 \\
\hline D_PRIVATE* & 0.06 & 0.23 & 0 & 1 \\
\hline AGE & 41 & 8.54 & 24 & 61 \\
\hline GEN* & 0.54 & 0.50 & 0 & 1 \\
\hline HEAD_KTO* & 0.28 & 0.45 & 0 & 1 \\
\hline FULL_IND* & 0.55 & 0.49 & 0 & 1 \\
\hline
\end{tabular}

Likert scale items devised to tap meaning, competence, self-determination, impact, task performance, organizational, citizenship behavior, intention to quit. More specifically, we used the multidimensional measure of perceived empowerment at the workplace proposed by Spreitzer (1995) and the one for perceived engagement proposed by Soane et al. (2012), which have been built using the items presented in perceived empowerment scale and perceived engagement scale.

To evaluate and explain performances in KT activities, it is necessary to identify their outcome, in our case represented by the number of license agreements (LICENSE), consistently with authors who have investigated knowledge transfer processes (Anderson et al., 2007; Belenzon and Schankerman, 2007; Chapple et al., 2005; Goh, 2002; Narteh, 2008; Siegel et al., 2003; Siegel et al., 2008; Campbell et al., 2020) who have used the same outcome variable (Chapple et al., 2005; Bican et al, 2017; Siegel et al., 2008; Thursby and Kemp, 2002).

Bercovitz and Feldman (2006) define KTOs' licenses as "the legal rights to use a specific part of university intellectual property." Several other studies on KTOs' performance use the number of license agreements or license income as an outcome variable (Macho-Stadler et al., 2007; Siegel et al., 2003; Ustundag et al., 2011). We followed Siegel et al. (2003), who used the annual number of licensing agreements and annual licensing income generated by universities and research organizations, as well as several other studies, which discussed the role of licensing as a tool for knowledge transfer (Lach and Schankerman, 2004; Thursby et al., 2001). Furthermore, a license agreement is a process that certainly involves a considerable commitment by knowledge transfer professionals (Inés MachoStadler et al., 2007; Lach and Schankerman, 2004; Owen-Smith, 2011; Thursby et al., 2001) and is therefore appropriate for our study. In fact, the relevance of this indicator is also linked to the fact that it involves a considerable commitment by KTPs, whose skills are particularly valuable in the various phases of the licensing process (from the first contacts with the licensee to the final agreement) (Inés Macho-Stadler et al., 2007; Lach and Schankerman, 2004; Owen-Smith, 2011; Thursby et al., 2001). 
Following Ageeva et al. (2018), we run a "confirmatory factor analysis" to assure the validity and reliability of the scale. For all our scales, we obtained satisfactory reliability represented by an $\alpha$ value ranging from 0.70 to 0.85 . Namely, our results support the construct homogeneity.

\subsection{Fuzzy-set qualitative comparative analysis}

By integrating qualitative and quantitative approaches, configurational comparative methods are helpful to complete prior studies (Fiss, 2007). Recently, such approach has been used in knowledge management (Cabrilo and Dahms, 2018; Del Sarto et al., 2019; Douglas et al., 2020; Lowik et al., 2016), organizational behavior (Frazier et al., 2016) and social science (Schneider and Wagemann, 2012) literature. These methods are appropriate to analyze systems that, starting from an initial status, may reach final states following different paths (Schneider and Wagemann, 2012; Cabrilo and Dahms, 2018). Accordingly, the aim of qualitative comparative analysis is to highlight patterns which supports the presence of casual relation (Schneider and Wagemann, 2012). Moreover, according to Ragin (2008), fsQCA is a valuable method also for the analysis of small samples.

In this study, a particular QCA technique has been used: fsQCA. fsQCA aims at establishing connections between combinations of causal conditions (i.e. meaning, competence, self-determination, impact, task, OCB, quit) and an outcome (i.e. license). The result of the analysis are recipes which summarize which combination of conditions are related to an outcome of interest (Mendel and Korjani, 2013). fsQCA works through several phases (Ragin, 2006); the first phase is generating a "truth table" reported in Table 2. The truth-table is a logically based mathematical table and reports all the possible combinations of casual conditions associated with an outcome (Ragin, 2006).

Phase two reduces the number of rows in the truth-table considering "frequency and consistency threshold." For this study, owing to the high number of cases in the sample, we used a "frequency threshold" of 3 and a "consistency threshold" of 0.80 (Russo et al., 2016). The third phase uses an algorithm to simplify the truth-table, and the solution is minimized and analyzed. In this phase, the authors must define how to logically handle the reminders by using one of three different techniques: "parsimonious solution, intermediate solution and complex solution" Del Sarto et al. (2019). The "parsimonious solution" includes all simplifying assumptions, without considering if they include easy or difficult counterfactuals, the "intermediate solution" includes simplifying assumptions by including easy counterfactuals, and the "complex solution" does not includes easy and difficult counterfactuals (Ragin, 2006).

Table 2 Truth table derived from fuzzy-set data

Conditions

Rows Meaning Competence Determination Impact Task OCB Quit cases Consist Consist

\begin{tabular}{rllllllllll}
\hline 1 & 1 & 0 & 0 & 1 & 0 & 1 & 0 & 8 & 0.98 & 0.98 \\
2 & 1 & 1 & 1 & 1 & 1 & 1 & 0 & 4 & 0.95 & 0.93 \\
3 & 0 & 1 & 0 & 0 & 0 & 0 & 0 & 2 & 0.58 & 0.2 \\
4 & 1 & 1 & 1 & 0 & 1 & 0 & 0 & 2 & 0.58 & 0.19 \\
5 & 1 & 0 & 0 & 1 & 1 & 1 & 0 & 2 & 0.98 & 0.97 \\
6 & 0 & 0 & 0 & 0 & 0 & 0 & 0 & 1 & 0.45 & 0.07 \\
7 & 1 & 1 & 0 & 0 & 0 & 0 & 0 & 1 & 0.66 & 0.28 \\
8 & 0 & 1 & 1 & 1 & 1 & 0 & 0 & 1 & 0.64 & 0.28 \\
9 & 1 & 1 & 0 & 0 & 1 & 1 & 0 & 1 & 0.84 & 0.56 \\
10 & 1 & 0 & 1 & 0 & 1 & 1 & 0 & 1 & 0.86 & 0.72 \\
11 & 0 & 1 & 1 & 0 & 1 & 1 & 0 & 1 & 0.76 & 0.44 \\
12 & 1 & 0 & 1 & 1 & 1 & 1 & 0 & 1 & 0.98 & 0.98
\end{tabular}

Notes: Rows are labeled as follows: 1 , membership in the set; 0 non-membership in the set. $2^{7}$. Further, we only present configurations that were exhibited by ate least one case in our data 


\subsection{Calibration}

To run fsQCA, calibration of variables is required. The calibration process is the process through which variables are operationalized as membership scores within predefined sets. The "direct method" is used to transform measurements into sets (Ragin, 2008).

Owing to the fact that the variables used in our study are not dichotomous, the variables have been transformed into fuzzy-set membership scores by using three qualitative anchors: threshold for "full membership in a set" (i.e. value 1); threshold for "full nonmembership in a set" (i.e. value 0); the "crossover point" (i.e. value 0.5) (Ragin, 2008). To manage multiple-item measures, items were combined into an average score (Leischnig and Kasper-Brauer, 2015; Russo et al., 2016). The three qualitative anchors used for the calibration, "full membership" (value 7), "full non-membership" (value 1) and the "crossover point" (value 4), were represented by the endpoints and the midpoints of the seven-point Likert scales (Gligor et al., 2019).

\section{Results}

\subsection{Analysis of necessary conditions}

Through the analysis of necessary conditions, the fsQCA determines if a causal condition is a "necessary condition" for the outcome to occur. It means that this analysis tests if a condition is necessary for the outcome, represented by licensing agreements. Following Schneider and Wagemann (2012), for a condition to be necessary its consistency must be greater than 0.9. As reported in Table 3, only the consistency of the condition $\sim$ Quit is higher than 0.9. For this reason, we can conclude that Quit is sufficient for the outcome to occur. As the consistency of other conditions is below the threshold of 0.9 , we conclude that none of the other conditions (e.g. meaning, competence, determination, impact, task, OCB, quit) are necessary for the outcome "License". As a consequence, only the absence of the condition Quit is sufficient for the output.

\subsection{Analysis of sufficient conditions}

The analysis of sufficient conditions identify which conditions are "sufficient" for the outcome to occur. In particular, in our study we used a "frequency threshold" of 3 and a "consistency threshold" of 0.8 . The use of such threshold are commonly accepted management literature (Cabrilo and Dahms, 2018; Del Sarto, et al., 2020; Lowik et al., 2016) because according to

\section{Table 3 Analysis of necessary conditions}

\begin{tabular}{|c|c|c|}
\hline Outcome: License agreements & Consistency & Coverage \\
\hline Meaning & 0.88 & 0.84 \\
\hline Meaning & 0.22 & 0.55 \\
\hline Competence & 0.52 & 0.72 \\
\hline Competence & 0.48 & 0.70 \\
\hline Determination & 0.50 & 0.71 \\
\hline Determination & 0.50 & 0.71 \\
\hline Impact & 0.24 & 0.81 \\
\hline 〜mpact & 0.76 & 0.68 \\
\hline Task & 0.51 & 0.82 \\
\hline Task & 0.48 & 0.62 \\
\hline $\mathrm{OCB}$ & 0.89 & 0.86 \\
\hline$\sim \mathrm{OCB}$ & 0.19 & 0.45 \\
\hline Quit & 0.06 & 0.56 \\
\hline$\sim$ Quit & 0.96 & 0.71 \\
\hline
\end{tabular}


Ragin $(2008,118)$, "No consistency values lower than 0.8 should be accepted." By using this frequency threshold, we consider as relevant cases only configurations that occur in more than one case. The model used for the analysis contains seven conditions:

\section{License $=f($ MEANING, COMPETENCE, DETERMINATION, IMPACT, TASK, OCB, QUIT)}

The fsQCA method allows the analysis of combinations of conditions that lead to the outcome of interest, in our case licensing agreements. The combinations are named "configurations".

We report the results of the analysis performed in Table 4. In this table show the configurations that are sufficient for the outcome "higher level of license agreements." For our analysis we use an "intermediate solution." The intermediate solution "can be understood as the complex solution reduced by the conditions that run counter to fundamental theoretical or substantive knowledge" (Schneider and Wagemann, 2012, p. 172). Moreover, according to Rihoux and De Meur (2009), the "intermediate solution" has considerable benefits over the parsimonious and the complex solution. We found that two configurations have consistency higher than 0.80 . Solution coverage and solution consistency are compliant with Ragin (2008) and Woodside (2012), according to whom consistency and coverage must be greater than 0.80 and 0.25 , respectively.

The first configuration is the following:

$$
\text { Meaning }{ }^{*} \text { Competence*} \text { Determination }{ }^{*} \text { Impact }^{*} \mathrm{OCB}^{*} \sim \text { Quit }
$$

The raw coverage of the first configuration is 0.34 , its unique coverage is 0.19 and its consistency is 0.95 . The first configuration highlights that $34 \%$ of the KTOs in which their managers have no intention of changing jobs have a higher level of license agreements.

The second configuration is as follows:

$$
\text { Meaning }{ }^{*} \sim \text { Competence }^{*} \sim \text { Determination }{ }^{*} \text { Impact }^{*} \sim \text { Task }^{*} \text { OCB }^{*} \sim \text { Quit }
$$

The raw coverage of the second configuration is 0.27 its unique coverage is 0.12 and its consistency is 0.96 . According to the second configuration, $27 \%$ of the KTOs in which their managers have a high level of organizational citizenship behavior, a high grade to which an individual manages to influence results at work (degree of impact) and a high level of level the value of a work goal (degree of the meaning), in this case, the KTOs generate a high level of license agreements.

An important finding from the analysis of the main configurations shows the co-presence of perceived engagement and perceived empowerment as a variable that leads to the outcome "license agreements", jointly with other factors. The level of organizational citizenship behavior; the degree to which an individual can influence strategic or operational results at work (degree of impact); the value of a work goal (degree of the meaning) are present in two of the three most important configurations. This result highlights

\section{Table 4 Analysis of sufficient conditions}

Raw coverage Uniquecoverage Consistency

\begin{tabular}{lccc}
\hline Meaning*Competence*Determination*Impact* & 0.34 & 0.19 & 0.95 \\
Task* OCB* Quit & & 0.12 & 0.96 \\
Meaning* $\sim$ Competence* $\sim$ Determination*Impact* & 0.27 & & \\
$\sim$ Task* OCB* Quit & & \\
Solution coverage: 0.47 & & \\
Solution consistency: 0.96 &
\end{tabular}


that knowledge transfer professionals who ( $\mathrm{i}$ have a discretionary behavior going beyond formal descriptions of the work, see their work environment as responding to their attempts to influence attempts (Spreitzer, 1995) and have confidence in their ability to carry on their activities (Gist, 1987) perform better.

Several authors argue that high employee performance is positively linked with perceived empowerment (Patterson et al., 2004; Thomas and Velthouse, 1990) and perceived engagement (Soane et al., 2012), but in this study, we highlight that only the combination of three cognitions heads an increase in the number of licenses agreements.

An analysis result shows that individual behavior is important for increasing KTO's performance and perceived empowerment and perceived engagement may interact with each other to increase KTOs' performance. However, only the combination of three individual cognitions increases performance in terms of the number of licenses agreements.

\section{Discussion}

The goal of this work was to analyze the performance of KTOs on the basis of the organizational behavior and the level of empowerment and engagement by KTPs. In particular, we investigated the following research question: "Is there a relationship between the interaction of individual cognitions of perceived empowerment and perceived engagement and KTOs' performance?"

Answering such a research question is important since previous studies have neglected to investigate the impact of individual cognitions - in our case, perceived empowerment and perceived engagement - in the empirical setting of KTOs (Akbari and Ghaffari, 2017; Fernandez and Moldogaziev, 2013; Kirkman and Benson, 1999; Rich et al., 2010; Yahya and Goh, 2002). To the best of our knowledge, our study is the first one that looks at the combined effect of the individual cognition of perceived engagement and perceived empowerment on KTOs' performances. Previous studies find significant and positive relationships on performances only when "engagement" and "empowerment" are observed in isolation and without considering KTOs' empirical setting (Akbari and Ghaffari, 2017; Conger and Kanungo, 1988; Dust et al., 2014; Salanova et al., 2005; Soane et al., 2012; Spreitzer, 1995, 2007; Kirkman and Benson, 1999; Yahya and Goh, 2002).

After analyzing which individual cognitions constitute the constructs of "perceived empowerment" (Spreitzer, 1995) and "perceived engagement" (Soane et al., 2012), we used the fsQCA approach, which allowed us to go deeper into the results of our study, while through confirmatory factor analysis, we tested if adopted scales are robust in terms of validity and reliability (Frazier et al., 2016).

The results of the fsQCA suggest that considering the multiple combination of individual cognitions the combination between a high level of organizational citizenship behavior, a high level of the degree to which an individual can influence strategic or operational results at work and a high level of the value of a work goal affect KTOs' performance. However, none of the individual cognitions alone or other combinations are capable of influencing the KTOs' performance.

\subsection{Theoretical implication}

Based on these findings, our study offers theoretical contributions which expand the literature on organizational behavior and knowledge management by providing additional elements about how to improve the performance of KTOs (Goh, 2002; Kumar and Ganesh, 2009; Romano et al., 2014). In particular, we offer three theoretical contributions.

First, our results point out that none of the individual cognitions of perceived empowerment and perceived engagement influences KTOs' performance in isolation. This result is in line with previous organizational behavior literature which has found that only the two constructs 
of "empowerment" and "engagement" have a significant and positive relationship on organizational performance (Dust et al., 2014; Patterson et al., 2004; Saks, 2006; Seibert et al., 2004; Spreitzer, 2007) and not the individual cognitions which constitute them.

Second, our results identify which combinations of individual cognitions are related to a KTO's performance contributing to the knowledge management literature. The level of organizational citizenship behavior, the degree to which an individual manages to influence results at work (degree of impact) and the value of a work goal (degree of the meaning) are the cognitions which generate a higher level of license agreements. The literature on knowledge transfer, in fact, has analyzed the impact of different organizational elements on KTOs performance (Chapple et al., 2005; Siegel et al., 2003), whereas our study highlight that individual behavior is also important for increasing KTOs' performance. Moreover, we found that the combination of individual cognitions of perceived empowerment (e.g. meaning and impact) with individual cognitions of perceived engagement (e.g. OCB) have an impact on KTOs' performance, suggesting that perceived empowerment and perceived engagement may interact with each other to increase KTOs' performance.

Third, our article contributes to the knowledge management literature highlighting that the willingness to change jobs is not related to the positive performance of a KTO. In particular, the absence of the willingness to quit the job in KTOs is positively related to a high level of the number of licenses. This result is consistent with previous literature on employee engagement (Kirschenbaum and Weisberg, 2003; Shuck et al., 2014) which found that the willingness to change the job is negatively related with the performance of organizations (Shore et al., 1990). Indeed, perceptions of a powerful organizational identity, a positive organizational climate and organizational empowerment and engagement affect employees' turnover intention in a distinctive way (Cole and Bruch, 2006). This result is also valid also when considering KTOs.

\subsection{Managerial implications}

In addition to theoretical contributions, our study provides some managerial implications which can be useful for KTO professionals, university managers and policymakers.

First, our results suggest that KTPs play a crucial role in knowledge transfer dynamics and, in particular, engagement and empowerment emerge as organizational supports which seem to be complementary rather than potentially substitutes. In other words, only when KTPs feel both empowered and engaged, there is a positive influence on KTOs performance. Moreover, our study shows that the individual cognitions of KTPs influence the performance of the KTO. However, to increase the degree of impact and meaning, specific actions of university managers may be necessary to legitimize the actions of KTPs. In fact, the degree of impact influences the value of the performance but is linked to the employees' legitimacy to act. Moreover, perceived engagement can also be seen as a combination of commitment to the organization and its values of helping colleagues with organizational citizenship behaviors. This implies that professional satisfaction alone is not enough, but it is necessary to create an environment conducive to motivation. University and KTPS managers should, therefore, improve job satisfaction of KTPs encouraging KTPs to share their ideas, recognize the results achieved, thus allowing them to develop different approaches to daily activities, providing growth and training opportunities and offering career development to increase the degree of organizational citizenship behaviors.

Second, as "impact" and "meaning" seem to be very important for KTPs, university rectors and top managers might perhaps intensify communication activities, both internally and externally, about the achievements of KTOs, especially in terms of the benefits produced for society as a whole. This should reinforce KTPs sense of belonging to their institution.

Third, our study shows that beyond motivating KTPs increasing their level of empowerment, they must also be provided with the necessary managerial tools, adequate for complex situations such as those which normally characterize KT processes. 


\section{Conclusions, future research and limitations}

In this study, we analyzed the relationship between the level of empowerment and engagement by KTPs and KTOs' performance. Understanding this relationship is important because previous studies have neglected to investigate the impact of individual cognitions in the empirical setting of KTOs (Akbari and Ghaffari, 2017; Fernandez and Moldogaziev, 2013). To address our research question (i.e. "Is there a relationship between the interaction of individual cognitions of perceived empowerment and perceived engagement and KTOs' performance?"), we drew on the literature on perceived organizational support to identify two individual cognitions influencing organizational performance, namely, perceived empowerment (Spreitzer, 1995) and perceived engagement (Soane et al., 2012), and we conducted an fsQCA analysis (Ragin and Beck, 1987) based on a survey submitted to KTOs professionals.

The results of the fuzzy set analysis highlighted the role of individual cognitions in influencing KTOs' performance contributing to the literature on organizational behavior, knowledge transfer and knowledge management.

As with all research, this study has limitations that provide avenues for future research. First, the study only focuses on the Italian context. Various studies have emphasized the specificities of the Italian technology transfer context (Bianchi and Piccaluga, 2012; Geuna and Muscio, 2009; Algieri et al., 2013; Baglieri et al., 2018) and replicating this study in other countries would be useful. Second, we limited our analysis of performance to license agreements. Other performance indicators can be used in the future. Finally, this research highlights the fact that the individual cognitions that interact with each other are part of both perceived empowerment and perceived engagement. In order to influence KTOs' performance, in fact, the cognitions meaning and impact, which are part of perceived empowerment, interact with OCB, which is part of a perceived engagement. For these reasons, further investigations about the correlation of perceived empowerment and perceived engagement in explaining KTOs' performance through quantitative methods are needed.

\section{Notes}

1. Netval is the Italian association for the valorisation of results from public research organizations. It includes 56 universities, 7 public research organisations, 6 research hospitals, 2 foundations and 1 agency.

2. The questionnaire is available on request.

\section{References}

Abell, P., Felin, T. and Foss, N. (2008), "Building micro-foundations for the routines, capabilities, and performance links", Managerial and Decision Economics, Vol. 29 No. 6, pp. 489-502.

Ageeva, E., Melewar, T.C., Foroudi, P., Dennis, C. and Jin, Z. (2018), "Examining the influence of corporate website favorability on corporate image and corporate reputation: findings from fsQCA", Journal of Business Research, Vol. 89, pp. 287-304.

Akbari, N. and Ghaffari, A. (2017), "Verifying relationship of knowledge management initiatives and the empowerment of human resources", Journal of Knowledge Management, Vol. 21 No. 5, pp. 1120-1141.

Alessandrini, M., Klose, K. and Pepper, M.S. (2013), "University entrepreneurship in South Africa: developments in technology transfer practices", Innovation, Vol. 15 No. 2, pp. 205-214.

Alfes, K., Truss, C., Soane, E.C., Rees, C. and Gatenby, M. (2013), "The relationship between line manager behavior, perceived HRM practices, and individual performance: examining the mediating role of engagement", Human Resource Management, Vol. 52 No. 6, pp. 839-859.

Algieri, B., Aquino, A. and Succurro, M. (2013), "Technology transfer offices and academic spin-off creation: the case of Italy", The Journal of Technology Transfer, Vol. 38 No. 4, pp. 382-400.

Allen, D.G., Shore, L.M. and Griffeth, R.W. (2003), "The role of perceived organizational support and supportive human resource practices in the turnover process", Journal of Management, Vol. 29 No. 1, pp. 99-118. 
Amidon, D.M. (1996), "Decade of perspective: a vision for the technology transfer profession", The Journal of Technology Transfer, Vol. 21 Nos 1/2, pp. 5-8.

Anderson, T.R., Daim, T.U. and Lavoie, F.F. (2007), "Measuring the efficiency of university technology transfer", Technovation, Vol. 27 No. 5, pp. 306-318.

Anitha, J. (2014), "Determinants of employee engagement and their impact on employee performance", International Journal of Productivity and Performance Management, Vol. 63 No. 3, pp. 308-323.

Ashforth, B.E. (1989), "The experience of powerlessness in organizations", Organizational Behavior and Human Decision Processes, Vol. 43 No. 2, pp. 207-242.

Bachouche, H. and Sabri, O. (2019), "Empowerment in marketing: synthesis, critical review, and agenda for future research", AMS Review, Vol. 9 Nos 3/4, pp. 304-323.

Baglieri, D., Baldi, F. and Tucci, C.L. (2018), "University technology transfer office business models: one size does not fit all", Technovation, Vols 76/77, pp. 51-63.

Baines, N. and Lawton Smith, H. (2020), "Knowledge and capabilities for products/services development: the UK spin-off firms context", Journal of Knowledge Management, Vol. 24 No. 4, pp. 941-962.

Bandura, A. (1986), Social Foundations of Thought and Action: A Social Cognitive Theory, Prentice Hall, Englewood Cliffs, NJ.

Bandura, A. (2007), "An agentic perspective on positive psychology", in Lopez, S.J. (Ed.), The Science of Human Flourishing, Praeger, New York, NY.

Bandura, A. and Locke, E.A. (2003), "Negative self-efficacy and goal effects revisited", Journal of Applied Psychology, Vol. 88 No. 1, p. 87.

Bekkers, R. and Freitas, I.M.B. (2008), "Analysing knowledge transfer channels between universities and industry: to what degree do sectors also matter?", Research Policy, Vol. 37 No. 10, pp. 1837-1853.

Belenzon, S. and Schankerman, M. (2007), "Harnessing success: determinants of university technology licensing performance", CEPR Discussion Paper, No. 6120.

Bercovitz, J. and Feldman, M. (2006), "Entrepreneurial universities and technology transfer: a conceptual framework for understanding knowledge-based economic development", The Journal of Technology Transfer, Vol. 31 No. 1, pp. 175-188.

Bercovitz, J. and Feldman, M. (2008), "Academic entrepreneurs: organizational change at the individual level", Organization Science, Vol. 19 No. 1, pp. 69-89.

Bercovitz, J., Feldman, M., Feller, I. and Burton, R. (2001), "Organizational structure as a determinant of academic patent and licensing behavior: an exploratory study of Duke, Johns Hopkins, and Pennsylvania State Universities", The Journal of Technology Transfer, Vol. 26 Nos 1/2, pp. 21-35.

Bhatnagar, J. (2005), "The power of psychological empowerment as an antecedent to organizational commitment in Indian managers", Human Resource Development International, Vol. 8 No. 4, pp. 419-433.

Bianchi, M. and Piccaluga, A. (2012), La Sfida Del Trasferimento Tecnologico: Le Università Italiane si Raccontano, Springer Science \& Business Media, Milan.

Bican, P.M., Guderian, C.C. and Ringbeck, A. (2017), "Managing knowledge in open innovation processes: an intellectual property perspective", Journal of Knowledge Management, Vol. 21 No. 6, pp. 1384-1405.

Bigliardi, B., Galati, F., Marolla, G. and Verbano, C. (2015), "Factors affecting technology transfer offices' performance in the Italian food context", Technology Analysis \& Strategic Management, Vol. 27 No. 4, pp. 361-384.

Bowen, D. and Lawler, E. (1992), "The empowerment of service workers: what, why, how, and when", Sloan Management Review, Vol. 33 No. 3, p. 9.

Brescia, F., Colombo, G. and Landoni, P. (2016), "Organizational structures of knowledge transfer offices: an analysis of the world's top-ranked universities", The Journal of Technology Transfer, Vol. 41 No. 1, pp. 132-151

Burke, M.J. and Day, R.R. (1986), "A cumulative study of the effectiveness of managerial training", Journal of Applied Psychology, Vol. 71 No. 2, p. 232 
Byrne, Z.S. and Hochwarter, W.A. (2008), "Perceived organizational support and performance", Journal of Managerial Psychology, Vol. 23 No. 1, pp. 54-72.

Cabrilo, S. and Dahms, S. (2018), "How strategic knowledge management drives intellectual capital to superior innovation and market performance", Journal of Knowledge Management, Vol. 22 No. 3, pp. 621-648.

Cameron, K. and Caza, A. (2002), "Organizational and leadership virtues and the role of forgiveness", Journal of Leadership \& Organizational Studies, Vol. 9 No. 1, pp. 33-48.

Campbell, A., Cavalade, C., Haunold, C., Karanikic, P. and Piccaluga, A. (2020), "Knowledge transfer metrics. Towards a European-wide set of harmonised indicators", in Karlsson Dinnetz, M. (Ed.), EUR 30218 EN, Publications Office of the European Union, Luxembourg, doi: 10.2760/907762_JRC120716.

Cardador, M.T., Dane, E. and Pratt, M.G. (2011), "Linking calling orientations to organizational attachment via organizational instrumentality", Journal of Vocational Behavior, Vol. 79 No. 2, pp. 367-378.

Carlsson, B. and Fridh, A.C. (2002), "Technology transfer in United States universities", Journal of Evolutionary Economics, Vol. 12 Nos 1/2, pp. 199-232.

Cesaroni, F. and Piccaluga, A. (2016), "The activities of university knowledge transfer offices: towards the third mission in Italy”, The Journal of Technology Transfer, Vol. 41 No. 4, pp. 753-777.

Chamberlin, M., Newton, D.W. and LePine, J.A. (2018), "A meta-analysis of empowerment and voice as transmitters of high-performance managerial practices to job performance", Journal of Organizational Behavior, Vol. 39 No. 10, pp. 1296-1313.

Chapple, W., Lockett, A., Siegel, D. and Wright, M. (2005), "Assessing the relative performance of UK university technology transfer offices: parametric and non-parametric evidence", Research Policy, Vol. 34 No. 3, pp. 369-384.

Chen, G., Kirkman, B.L., Kanfer, R., Allen, D. and Rosen, B. (2007), "A multilevel study of leadership, empowerment, and performance in teams", Journal of Applied Psychology, Vol. 92 No. 2, p. 331.

Chong, S., Van Dyne, L., Kim, Y.J. and Oh, J.K. (2020), "Drive and direction: empathy with intended targets moderates the proactive personality - job performance relationship via work engagement", Applied Psychology, pp. 1-31.

Clark, M.A., Robertson, M.M. and Young, S. (2019), "'I feel your pain': a critical review of organizational research on empathy", Journal of Organizational Behavior, Vol. 40 No. 2, pp. 166-192.

Colcelli, V. (2019), "Technology transfer professional”, in Bartolini, A., Cippitani, R. and Colcelli, V. (Eds), Dictionary of Statuses within EU Law, Springer, Cham.

Cole, N. (1995), "How employee empowerment improves manufacturing performance", Academy of Management Perspectives, Vol. 9 No. 1, pp. 80-80.

Cole, M.S. and Bruch, H. (2006), "Organizational identity strength, identification, and commitment and their relationships to turnover intention: does organizational hierarchy matter?", Journal of Organizational Behavior, Vol. 27 No. 5, pp. 585-605.

Conger, J.A. and Kanungo, R.N. (1988), "The empowerment process: integrating theory and practice", Academy of Management Review, Vol. 13 No. 3, pp. 471-482.

Cotton, J.L., Vollrath, D.A., Froggatt, K.L., Lengnick-Hall, M.L. and Jennings, K.R. (1988), "Employee participation: diverse forms and different outcomes", Academy of Management Review, Vol. 13 No. 1, pp. 8-22.

Coyne, I. and Ong, T. (2007), "Organizational citizenship behaviour and turnover intention: a crosscultural study", The International Journal of Human Resource Management, Vol. 18 No. 6, pp. 1085-1097.

Cunningham, J.A., Harney, B. and Fitzgerald, C. (2020), "Technology transfer offices: roles, activities, and responsibilities”, Effective Technology Transfer Offices, Springer, Cham, pp. 1-14.

Dane, E. and Brummel, B.J. (2014), "Examining workplace mindfulness and its relations to job performance and turnover intention”, Human Relations, Vol. 67 No. 1, pp. 105-128.

Deci, E.L., Olafsen, A.H. and Ryan, R.M. (2017), "Self-determination theory in work organizations: the state of a science", Annual Review of Organizational Psychology and Organizational Behavior, Vol. 4 No. 1, pp. 19-43.

Degago, E. (2014), "A study on impact of psychological empowerment on employee performance in small and medium scale enterprise sectors", European Journal of Business and Management, Vol. 6 No. 27 , pp. 60-72. 
DeGeeter, M.J. (2004), Technology Commercialization Manual: Strategy, Tactics and Economics for Business Success, Med-Launch, Inc.

Del Sarto, N., Isabelle, D.A. and Di Minin, A. (2020), "The role of accelerators in firm survival: an fsQCA analysis of Italian startups", Technovation, Vols 90/91, p. 102102.

Del Sarto, N., Di Minin, A., Ferrigno, G. and Piccaluga, A. (2019), "Born global and well educated: start-up survival through fuzzy set analysis", Small Business Economics, pp. 1-19.

DeVol, R.C., Bedroussian, A., Babayan, A., Frye, M., Murphy, D., Philipson, T.J., Wallace, L., Wong, P. and Yeo, B. (2006), Mind to Market: A Global Analysis of University Biotechnology Transfer and Commercialization, Milken Institute, Santa Monica, CA.

Dillman, D.A. (2000), Mail and Internet Surveys: The Tailored Design Method, Vol. 2, Wiley, New York, NY.

Dittrich, J.E. and Carrell, M.R. (1979), "Organizational equity perceptions, employee job satisfaction, and departmental absence and turnover rates", Organizational Behavior and Human Performance, Vol. 24 No. 1, pp. 29-40.

Douglas, E.J., Shepherd, D.A. and Prentice, C. (2020), "Using fuzzy-set qualitative comparative analysis for a finer-grained understanding of entrepreneurship", Journal of Business Venturing, Vol. 35 No. 1, p. 105970.

Dunlop, P.D. and Lee, K. (2004), "Workplace deviance, organizational citizenship behavior, and business unit performance: the bad apples do spoil the whole barrel", Journal of Organizational Behavior, Vol. 25 No. 1, pp. 67-80.

Dust, S.B., Resick, C.J. and Mawritz, M.B. (2014), "Transformational leadership, psychological empowerment, and the moderating role of mechanistic-organic contexts", Journal of Organizational Behavior, Vol. 35 No. 3, pp. 413-433.

Ehrhart, M.G. and Naumann, S.E. (2004), "Organizational citizenship behavior in work groups: a group norms approach”, Journal of Applied Psychology, Vol. 89 No. 6, pp. 960-974.

Eisenberger, R., Huntington, R., Hutchison, S. and Sowa, D. (1986), "Perceived organizational support", Journal of Applied Psychology, Vol. 71 No. 3, p. 500.

Eisenberger, R., Stinglhamber, F., Vandenberghe, C., Sucharski, I.L. and Rhoades, L. (2002), "Perceived supervisor support: contributions to perceived organizational support and employee retention", Journal of Applied Psychology, Vol. 87 No. 3, p. 56.

Fai, F.M., de Beer, C. and Schutte, C.S. (2018), "Towards a novel technology transfer office typology and recommendations for developing countries”, Industry and Higher Education, Vol. 32 No. 4, pp. 213-225.

Felin, T. and Foss, N.J. (2005), "Strategic organization: a field in search of micro-foundations".

Felin, T. and Hesterly, W.S. (2007), "The knowledge-based view, nested heterogeneity, and new value creation: philosophical considerations on the locus of knowledge", Academy of Management Review, Vol. 32 No. 1, pp. 195-218.

Fernandez, S. and Moldogaziev, T. (2011), "Empowering public sector employees to improve performance: does it work?", The American Review of Public Administration, Vol. 41 No. 1, pp. 23-47.

Fernandez, S. and Moldogaziev, T. (2013), "Employee empowerment, employee attitudes, and performance: testing a causal model", Public Administration Review, Vol. 73 No. 3, pp. 490-506.

Fernández-López, S., Rodeiro-Pazos, D., Calvo, N. and Rodríguez-Gulías, M.J. (2018), "The effect of strategic knowledge management on the universities' performance: an empirical approach", Journal of Knowledge Management, Vol. 22 No. 3, pp. 567-586.

Fong, K.H. and Snape, E. (2015), "Empowering leadership, psychological empowerment and employee outcomes: testing a multi-level mediating model", British Journal of Management, Vol. 26 No. 1, pp. 126-138.

Frazier, M.L., Tupper, C. and Fainshmidt, S. (2016), "The path(s) to employee trust in direct supervisor in nascent and established relationships: a fuzzy set analysis", Journal of Organizational Behavior, Vol. 37 No. 7, pp. 1023-1043.

Gagné, M. and Deci, E.L. (2005), "Self-determination theory and work motivation", Journal of Organizational Behavior, Vol. 26 No. 4, pp. 331-362.

Geuna, A. and Muscio, A. (2009), "The governance of university knowledge transfer: a critical review of the literature”, Minerva, Vol. 47 No. 1, pp. 93-114. 
Ghoshal, S. and Bartlett, C.A. (1994), "Linking organizational context and managerial action: the dimensions of quality of management”, Strategic Management Journal, Vol. 15 No. S2, pp. 91-112.

Gist, M.E. (1987), "Self-efficacy: implications for organizational behavior and human resource management", Academy of Management Review, Vol. 12 No. 3, pp. 472-485.

Gioia, D.A. and Manz, C.C. (1985), "Linking cognition and behavior: a script processing interpretation of vicarious learning", Academy of Management Review, Vol. 10 No. 3, pp. 527-539.

Gligor, D., Bozkurt, S. and Russo, I. (2019), "Achieving customer engagement with social media: a qualitative comparative analysis approach", Journal of Business Research, Vol. 101, pp. 59-69.

Goh, S.C. (2002), "Managing effective knowledge transfer: an integrative framework and some practice implications", Journal of Knowledge Management, Vol. 6 No. 1, pp. 23-30.

González-Romá, V., Schaufeli, W.B., Bakker, A.B. and Lloret, S. (2006), "Burnout and work engagement: independent factors or opposite poles?", Journal of Vocational Behavior, Vol. 68 No. 1, pp. 165-174.

Gregory, B.T., Albritton, M.D. and Osmonbekov, T. (2010), "The mediating role of psychological empowerment on the relationships between $\mathrm{P}-\mathrm{O}$ fit, job satisfaction, and in-role performance", Journal of Business and Psychology, Vol. 25 No. 4, pp. 639-647.

Grimpe, C. and Hussinger, K. (2013), "Formal and informal knowledge and technology transfer from academia to industry: complementarity effects and innovation performance", Industry \& Innovation, Vol. 20 No. 8, pp. 683-700.

Gruman, J.A. and Saks, A.M. (2011), "Performance management and employee engagement", Human Resource Management Review, Vol. 21 No. 2, pp. 123-136.

Guthrie, J.P. (1998), "High-Involvement work practices, turnover and productivity: evidence from New Zealand", The Academy of Management Journal, Vol. 2 No. 1, pp. 180-190.

Halbesleben, J.R.B. and Wheeler, A.R. (2008), "The relative roles of engagement and embeddedness in predicting job performance and intention to leave", Work \& Stress, Vol. 22 No. 3, pp. 242-256.

Hao, P., He, W. and Long, L.R. (2018), "Why and when empowering leadership has different effects on employee work performance: the pivotal roles of passion for work and role breadth self-efficacy", Journal of Leadership \& Organizational Studies, Vol. 25 No. 1, pp. 85-100.

Harman, G. and Stone, C. (2006), "Australian university technology transfer managers: backgrounds, work roles, specialist skills and perceptions", Journal of Higher Education Policy and Management, Vol. 28 No. 3, pp. 213-230.

Hom, P.W. and Griffeth, R.W. (1995), Employee Turnover, International Thomson, Cincinnati, OH.

Hülsbeck, M., Lehmann, E.E. and Starnecker, A. (2013), "Performance of technology transfer offices in Germany", The Journal of Technology Transfer, Vol. 38 No. 3, pp. 199-215.

Jenkins, M. and Johnson, G. (1997), "Linking managerial cognition and organizational performance: a preliminary investigation using causal maps", British Journal of Management, Vol. 8 No. s1, pp. 77-90.

Joo, B.K. and Shim, J.H. (2010), "Psychological empowerment and organizational commitment: the moderating effect of organizational learning culture", Human Resource Development International, Vol. 13 No. 4, pp. 425-441.

Kahn, W.A. (1990), "Psychological conditions of personal engagement and disengagement at work", Academy of Management Journal, Vol. 33 No. 4, pp. 692-724.

Kanter, R. (1983), The Change Masters: Innovations for Productivity in the American Corporation, Simon \& Schuster, New York, NY.

Khan, A.A. (1992), "Preplant physiological seed conditioning", Horticultural Reviews, Vol. 13 No. 1, pp. 131-181.

Kirkman, B. and Benson, R. (1999), "Beyond self-management: antecedents and consequences of team empowerment”, Academy of Management, Vol. 42 No. 1, pp. 58-74.

Kirschenbaum, A. and Weisberg, J. (2003), "Employee's turnover intentions and job destination choices", Journal of Organizational Behavior, Vol. 23 No. 1, pp. 109-125.

Klein, G. (1998), Sources of Power: How People Make Decisions, MIT Press Cardador MT, Cambridge, MA. 
Klotz, A.C., Bolino, M.C., Song, H. and Stornelli, J. (2018), "Examining the nature, causes, and consequences of profiles of organizational citizenship behavior", Journal of Organizational Behavior, Vol. 39 No. 5, pp. 629-647.

Kumar, J.A. and Ganesh, L.S. (2009), "Research on knowledge transfer in organizations: a morphology", Journal of Knowledge Management, Vol. 13 No. 4, pp. 161-174.

Lach, S. and Schankerman, M. (2004), "Royalty sharing and technology licensing in universities", Journal of the European Economic Association, Vol. 2 Nos 2/3, pp. 252-264.

Lafuente, E. and Berbegal-Mirabent, J. (2019), "Assessing the productivity of technology transfer offices: an analysis of the relevance of aspiration performance and portfolio complexity", The Journal of Technology Transfer, Vol. 44 No. 3, pp. 778-801.

Lai, J.Y.M., Lam, L.W. and Lam, S.S.K. (2013), "Organizational citizenship behavior in work groups: a team cultural perspective", Journal of Organizational Behavior, Vol. 34 No. 7, pp. 1039-1056.

Lamm, E., Tosti-Kharas, J. and King, C.E. (2015), "Empowering employee sustainability: perceived organizational support toward the environment", Journal of Business Ethics, Vol. 128 No. 1, pp. 207-220.

Leischnig, A. and Kasper-Brauer, K. (2015), "Employee adaptive behavior in service enactments", Journal of Business Research, Vol. 68 No. 2, pp. 273-280.

Lockett, A. and Wright, M. (2005), "Resources, capabilities, risk capital and the creation of university spinout companies", Research Policy, Vol. 34 No. 7, pp. 1043-1057.

Lofquist, E.A., Isaksen, S.G. and Dahl, T.J. (2017), "Exploring change, job engagement and work environment in the Norwegian Directorate of Fisheries", Academy of Management Proceedings, Vol. 2017 No. 1, p. 12841.

Lowik, S., Kraaijenbrink, J. and Groen, A. (2016), "The team absorptive capacity triad: a configurational study of individual, enabling, and motivating factors", Journal of Knowledge Management, Vol. 20 No. 5, pp. 1083-1103.

Luthans, F. (2002), "The need for and meaning of positive organizational behavior", Journal of Organizational Behavior: The International Journal of Industrial, Occupational and Organizational Psychology and Behavior, Vol. 23 No. 6, pp. 695-706.

Luthans, F., Youssef, C.M. and Avolio, B.J. (2007), "Psychological capital: investing and developing positive organizational behavior", Positive Organizational Behavior, Vol. 1 No. 2, pp. 9-24.

Luthans, F., Norman, S.M., Avolio, B.J. and Avey, J.B. (2008), "The mediating role of psychological capital in the supportive organizational climate - employee performance relationship", Journal of Organizational Behavior: The International Journal of Industrial, Occupational and Organizational Psychology and Behavior, Vol. 29 No. 2, pp. 219-238.

Macey, W.H. and Schneider, B. (2008), "The meaning of employee engagement", Industrial and Organizational Psychology, Vol. 1 No. 1, pp. 3-30.

Macho-Stadler, I., Pérez-Castrillo, D. and Veugelers, R. (2007), "Licensing of university inventions: the role of a technology transfer office", International Journal of Industrial Organization, Vol. 25 No. 3, pp. 483-510.

Markman, G.D., Gianiodis, P.T., Phan, H.P. and Balkin, D.B. (2005), "Speed to market as a success factor in technology transfer", Research Policy, Vol. 34 No. 7, pp. 1058-1075.

Markos, S. and Sridevi, M.S. (2010), "Employee engagement: the key to improving performance", International Journal of Business and Management, Vol. 5 No. 12, p. 89.

Mendel, J.M. and Korjani, M.M. (2013), "Theoretical aspects of fuzzy set qualitative comparative analysis (fsQCA)", Information Sciences, Vol. 237, pp. 137-161.

Meyer, J.P., Stanley, D.J., Herscovitch, L. and Topolnytsky, L. (2002), "Affective, continuance, and normative commitment to the organization: a meta-analysis of antecedents, correlates, and consequences", Journal of Vocational Behavior, Vol. 61 No. 1, pp. 20-52.

Miller, F.A., Sanders, C.B. and Lehoux, P. (2009), "Imagining value, imagining users: academic technology transfer for health innovation", Social Science \& Medicine, Vol. 68 No. 8, pp. 1481-1488.

Mom, T., Oshri, I. and Volberda, H.W. (2012), "The skill base of technology transfer professionals", Technology Analysis \& Strategic Management, Vol. 24 No. 9, pp. 871-891. 
Morris, J.A., Brotheridge, C.M. and Urbanski, J.C. (2005), "Bringing humility to leadership: antecedents and consequences of leader humility”, Human Relations, Vol. 58 No. 10, pp. 1323-1350.

Morrison, E.W. (1996), "Organizational citizenship behavior as a critical link between HRM practices and service quality", Human Resource Management, Vol. 35 No. 4, pp. 493-512.

Morse, J.J. (1976), "Sense of competence and individual managerial performance", Psychological Reports, Vol. 38 No. 3_suppl, pp. 1195-1198.

Mowday, R.T. (1978), "The exercise of upward influence in organizations", Administrative Science Quarterly, Vol. 23 No. 1, p. 137.

Narteh, B. (2008), "Knowledge transfer in developed-developing country interfirm collaborations: a conceptual framework", Journal of Knowledge Management, Vol. 12 No. 1, pp. 78-91.

Netval (2019), Annual Report 2019.

Organ, D.W. (1988), "A restatement of the satisfaction-performance hypothesis", Journal of Management, Vol. 14 No. 4, pp. 547-557.

Organ, D.W. and Ryan, K. (1995), "A meta-analytic review of attitudinal and dispositional predictors of organizational citizenship behavior”, Personnel Psychology, Vol. 48 No. 4, pp. 775-802.

Organ, D.W., Podsakoff, P.M. and MacKenzie, S.B. (2006), Organizational Citizenship Behavior: Its Nature, Antecedents, and Consequences, Sage, Thousand Oaks, CA.

Owens, B.P., Johnson, M.D. and Mitchell, T.R. (2013), “Expressed humility in organizations: implications for performance, teams, and leadership", Organization Science, Vol. 24 No. 5, pp. 1517-1538.

Owen-Smith, J. (2011), "The institutionalization of expertise in university licensing", Theory and Society, Vol. 40 No. 1, pp. 63-94.

Patterson, M.G., West, M.A. and Wall, T.D. (2004), "Integrated manufacturing, empowerment, and company performance", Journal of Organizational Behavior, Vol. 25 No. 5, pp. 641-665.

Perkmann, M., Tartari, V., McKelvey, M., Autio, E., Broström, A., D’Este, P., Fini, R., Geuna, A., Grimaldi, R., Hughes, A. and Krabel, S. (2013), "Academic engagement and commercialisation: a review of the literature on university-industry relations", Research Policy, Vol. 42 No. 2, pp. 423-442.

Phan, P.H.C. and Siegel, D.S. (2006), The Effectiveness of University Technology Transfer, Now Publishers Inc, Hanover, MA.

Ragin, C.C. (2006), "Set relations in social research: evaluating their consistency and coverage", Political Analysis, pp. 291-310.

Ragin, C.C. (2008), "Measurement versus calibration: a set-theoretic approach", The Oxford Handbook of Political Methodology.

Ragin, C. and Beck, B. (1987), "Fostering diversity: graduate study in sociology at Northwestern University", The American Sociologist, Vol. 18 No. 1, pp. 92-96.

Rhoades, L., Eisenberger, R. and Armeli, S. (2001), "Affective commitment to the organization: the contribution of perceived organizational support", Journal of Applied Psychology, Vol. 86 No. 5, p. 825.

Rich, B., LePine, J.A. and Crawford, E.R. (2010), "Job engagement: antecedents and effects on job performance”, Academy of Management Journal, Vol. 53 No. 3, pp. 617-635.

Rigby, C.S. and Ryan, R.M. (2018), "Self-determination theory in human resource development: new directions and practical considerations", Advances in Developing Human Resources, Vol. 20 No. 2, pp. 133-147.

Rihoux, B. and De Meur, G. (2009), "Crisp-set qualitative comparative analysis (csQCA)", Configurational Comparative Methods: Qualitative Comparative Analysis (QCA) and Related Techniques, Vol. 51, pp. 33-68.

Robbins, T., Crino, M. and Fredendall, L. (2002), "An integrative model of the empowerment process", Human Resource Management Review, Vol. 12 No. 3, pp. 419-443, doi: 10.1016/s1053-4822(02)00068-2.

Romano, M., Del Giudice, M. and Nicotra, M. (2014), "Knowledge creation and exploitation in Italian universities: the role of internal policies for patent activity", Journal of Knowledge Management, Vol. 18 No. 5, pp. 952-970.

Russo, I., Confente, I., Gligor, D.M. and Autry, C.W. (2016), "To be or not to be (loyal): is there a recipe for customer loyalty in the B2B context?", Journal of Business Research, Vol. 69 No. 2, pp. 888-896. 
Ryan, R.M. and Deci, E.L. (2017), Self-Determination Theory: Basic Psychological Needs in Motivation, Development, and Wellness, Guilford, New York, NY.

Saks, A.M. (2006), "Antecedents and consequences of employee engagement", Journal of Managerial Psychology, Vol. 21 No. 7, pp. 600-619.

Saks, A.M., Leck, J.D. and Saunders, D.M. (1995), "Effects of application blanks and employment equity on applicant reactions and job pursuit intentions", Journal of Organizational Behavior, Vol. 16 No. 5, pp. 415-430.

Salanova, M., Agut, S. and Peiró, J.M. (2005), "Linking organizational resources and work engagement to employee performance and customer loyalty: the mediation of service climate", Journal of Applied Psychology, Vol. 90 No. 6, pp. 1217-1227.

Sandelin, J. (2003), "Success factors in patenting and licensing", InnovationMatters, Vol. 15 No. 15, p. 10.

Santoro, M.D. and Bierly, P.E. (2006), "Facilitators of knowledge transfer in university-industry collaborations: a knowledge-based perspective", IEEE Transactions on Engineering Management, Vol. 53 No. 4, pp. 495-507

Schneider, C.Q. and Wagemann, C. (2012), Set-Theoretic Methods for the Social Sciences: A Guide to Qualitative Comparative Analysis, Cambridge University Press, Cambridge.

Seibert, S.E., Silver, S.R. and Randolph, W.A. (2004), "Taking empowerment to the next level: a multiplelevel model of empowerment, performance, and satisfaction", Academy of Management Journal, Vol. 47 No. 3, pp. 332-349.

Sellenthin, M.O. (2009), "Technology transfer offices and university patenting in Sweden and Germany", The Journal of Technology Transfer, Vol. 34 No. 6, pp. 603-620.

Shane, S. and Stuart, T. (2002), "Organizational endowments and the performance of university start-ups", Management Science, Vol. 48 No. 1, pp. 154-170.

Shanock, L.R. and Eisenberger, R. (2006), "When supervisors feel supported: relationships with subordinates' perceived supervisor support, perceived organizational support, and performance", Journal of Applied Psychology, Vol. 91 No. 3, p. 689.

Shore, L.M., Newton, L.A. and Thornton, G.C. (1990), "Job and organizational attitudes in relation to employee behavioral intentions”, Journal of Organizational Behavior, Vol. 11 No. 1, pp. 57-67.

Shuck, B., Twyford, D., Reio, T.G., Jr,. and Shuck, A. (2014), "Human resource development practices and employee engagement: examining the connection with employee turnover intentions", Human Resource Development Quarterly, Vol. 25 No. 2, pp. 239-270.

Shuck, B. and Wollard, K. (2010), "Employee engagement and HRD: a seminal review of the foundations", Human Resource Development Review, Vol. 9 No. 1, pp. 89-110.

Siegel, D., Veugelers, R. and Wright, M. (2007), "Technology transfer offices and commercialization of university intellectual property: performance and policy implications", Oxford Review of Economic Policy, Vol. 23 No. 4, pp. 640-660.

Siegel, D., Waldman, D. and Link, A. (2003), "Assessing the impact of organizational practices on the relative productivity of university technology transfer offices: an exploratory study", Research Policy, Vol. 32 No. 1, pp. 27-48.

Siegel, D., Wright, M., Chapple, W. and Lockett, A. (2008), "Assessing the relative performance of university technology transfer in the US and UK: a stochastic distance function approach", Economics of Innovation and New Technology, Vol. 17 Nos 7/8, pp. 717-729.

Singh, S.K. and Singh, A.P. (2019), "Interplay of organizational justice, psychological empowerment, organizational citizenship behavior, and job satisfaction in the context of circular economy", Management Decision, Vol. 57 No. 4, pp. 937-952.

Snape, E. and Redman, T. (2010), "HRM practices, organizational citizenship behaviour, and performance: a multi-level analysis", Journal of Management Studies, Vol. 47 No. 7, pp. 1219-1247.

Soane, E., Truss, C., Alfes, K., Shantz, A., Rees, C. and Gatenby, M. (2012), "Development and application of a new measure of employee engagement: the ISA engagement scale", Human Resource Development International, Vol. 15 No. 5, pp. 529-547.

Sonnentag, S. and Frese, M. (2002), "Performance concepts and performance theory", Psychological Management of Individual Performance, Vol. 23 No. 1, pp. 3-25. 
Spector, P.E. and Jex, S.M. (1998), "Development of four self-report measures of job stressors and strain: interpersonal conflict at work scale, organizational constraints scale, quantitative workload inventory, and physical symptoms inventory", Journal of Occupational Health Psychology, Vol. 3 No. 4,356 .

Spreitzer, G. (2007), "Giving peace a chance: organizational leadership, empowerment, and peace", Journal of Organizational Behavior, Vol. 28 No. 8, pp. 1077-1095.

Spreitzer, G.M. (1995), "Psychological empowerment in the workplace: dimensions, measurement and validation", Academy of Management Journal, Vol. 38 No. 5, pp. 1442-1465.

Spreitzer, G.M., De Janasz, S.C. and Quinn, R.E. (1999), "Empowered to lead: the role of psychological empowerment in leadership", Journal of Organizational Behavior, Vol. 20 No. 4, pp. 511-526.

Thomas, K.W. and Velthouse, B.A. (1990), "Cognitive elements of empowerment: an 'interpretive' model of intrinsic task motivation", The Academy of Management Review, Vol. 15 No. 4, pp. 666-681.

Thursby, J., Jensen, R. and Thursby, M.C. (2001), "Objectives, characteristics and outcomes of university licensing: a survey of major US Universities", The Journal of Technology Transfer, Vol. 26 Nos 1/2, pp. 59-72.

Thursby, J.G. and Kemp, S. (2002), "Growth and productive efficiency of university intellectual property licensing”, Research Policy, Vol. 31 No. 1, pp. 109-124.

Truss, C., Alfes, K., Delbridge, R., Shantz, A. and Soane, E. (Eds) (2013), Employee Engagement in Theory and Practice, Routledge.

Ugboro, I.O. and Obeng, K. (2000), "Top management leadership, employee empowerment, job satisfaction, and customer satisfaction in TQM organizations: an empirical study", Journal of Quality Management, Vol. 5 No. 2, pp. 247-272.

Ustundag, A., Ugurlu, S. and Kilinc, M.S. (2011), "Evaluating the performance of technology transfer offices", Journal of Enterprise Information Management, Vol. 24 No. 4, pp. 322-337.

Van Knippenberg, D. (2000), "Work motivation and performance: a social identity perspective", Applied Psychology, Vol. 49 No. 3, pp. 357-371.

Vigoda-Gadot, E., Eldor, L. and Schohat, L.M. (2013), "Engage them to public service: conceptualization and empirical examination of employee engagement in public administration", The American Review of Public Administration, Vol. 43 No. 5, pp. 518-538.

Volberda, H.W., Oshri, I. and Mom, T.J.M. (2012), "Technology transfer: the practice and the profession", Technology Analysis \& Strategic Management, Vol. 24 No. 9, pp. 863-869.

Von Krogh, G. (1998), "Care in knowledge creation", California Management Review, Vol. 40 No. 3 , pp. 133-153.

Von Krogh, G., Ichijo, K. and Nonaka, I. (2000), Enabling Knowledge Creation: How to Unlock the Mystery of Tacit Knowledge and Release the Power of Innovation, Oxford University Press on Demand.

Walker, H.J., Feild, H.S., Giles, W.F., Bernerth, J.B. and Jones-Farmer, L.A. (2007), "An assessment of attraction toward affirmative action organizations: investigating the role of individual differences", Journal of Organizational Behavior, Vol. 28 No. 4, pp. 485-507.

Wang, Y. (2011), "Mission-driven organizations in Japan: management philosophy and individual outcomes", Journal of Business Ethics, Vol. 101 No. 1, pp. 111-126.

Wolson, R.A. (2007), "The role of technology transfer offices in building the South African biotechnology sector: an assessment of policies, practices and impact", The Journal of Technology Transfer, Vol. 32 No. 4, pp. 343-365.

Yahya, S. and Goh, W.K. (2002), "Managing human resources toward achieving knowledge management", Journal of Knowledge Management, Vol. 6 No. 5, pp. 457-468.

Zayas-Ortiz, M., Rosario, E., Marquez, E. and Gruneiro, P.C. (2015), "Relationship between organizational commitments and organizational citizenship behaviour in a sample of private banking employees", International Journal of Sociology and Social Policy, Vol. 35 Nos 1/2.

Zhong, L., Wayne, S.J. and Liden, R.C. (2016), "Job engagement, perceived organizational support, high-performance human resource practices, and cultural value orientations: a cross-level investigation", Journal of Organizational Behavior, Vol. 37 No. 6, pp. 823-844 


\section{Further reading}

Agocs, C. and Burr, C. (1996), "Employment equity, affirmative action and managing diversity: assessing the differences", International Journal of Manpower, Vol. 17 Nos 4/5, pp. 30-45.

Allen, R.W., Porter, L.W. and Angle, H.L. (2016), Organizational Influence Processes, Routledge, New York, NY.

Bandura, A. (2008), "An agentic perspective on positive psychology", Positive Psychology, Vol. 1, pp. 167-196.

Dane, E. and Pratt, M.G. (2011), "Linking calling orientations to organizational attachment via organizational instrumentality", Journal of Vocational Behavior, Vol. 79 No. 2, pp. 367-378.

Hackaday, T. (2020), Technology Transfer Innovation, Johns Hopkins University Press.

Harter, J.K., Schmidt, F.L. and Hayes, T.L. (2002), "Business-unit-level relationship between employee satisfaction, employee engagement, and business outcomes: a meta-analysis", Journal of Applied Psychology, Vol. 87 No. 2, pp. 268-279.

Jensen, B.R. and Thursby, M. (2016), "American economic association proofs and prototypes for sale: the licensing of university inventions", American Economic Review, Vol. 91 No. 1, pp. 240-259.

O'Shea, R.P., Allen, T.J., Chevalier, A. and Roche, F. (2005), "Entrepreneurial orientation, technology transfer and spinoff performance of US universities", Research Policy, Vol. 34 No. 7, pp. 994-1009.

\section{About the authors}

Valentina Cucino is Postdoctoral Scholar at Scuola Superiore Sant'Anna, Pisa. She received her $\mathrm{PhD}$ in Management Innovation, Sustainability and Healthcare from Scuola Superiore Sant'Anna in 2019. Her research interest deals with knowledge management, humane resource management, organizational behavior and leadership.

Nicola Del Sarto is Post-doctoral research fellow at Scuola Superiore Sant'Anna in Pisa. He received $\mathrm{PhD}$ in Management of Innovation, Sustainability and Healthcare from Scuola Superiore Sant'Anna in 2019. Nicola's research interests focus on small businesses and start-ups and support mechanisms such as incubators, accelerators and corporate accelerator programs. Moreover, he is investigating the processes of business creation under the Open Innovation paradigm. Nicola's work has been published in high-quality peer reviewed journals and presented at international conferences. Nicola Del Sarto is the corresponding author and can be contacted at: nicola.delsarto@santannapisa.it

Alberto Di Minin is Full Professor of Management at the Scuola Superiore Sant'Anna in Pisa. Alberto's research deals with Open Innovation, appropriation of innovation and Science and Technology Policy. In particular, he focuses on open innovation and new business models. $\mathrm{He}$ also works on technology transfer, intellectual property and R\&D management. His latest publications appeared on California Management Review, Journal of International Business Studies, R\&D Management Journal, Research Policy.

Andrea Piccaluga is Full Professor of Innovation Management at the Institute of Management and delegate for Technology Transfer at Scuola Superiore Sant'Anna, Pisa. He has published several articles in leading management journals, including $R \& D$ Management Journal, Small Business Economics, California Management Review, Journal of Technology Transfer, Journal of Knowledge Management, Technology Analysis \& Strategic Management, European Management Journal and Creativity and Innovation Management. His research and teaching mainly deal with R\&D and innovation management; open innovation and the collaboration between firms and research institutions in the innovation process.

For instructions on how to order reprints of this article, please visit our website:

www.emeraldgrouppublishing.com/licensing/reprints.htm

Or contact us for further details: permissions@emeraldinsight.com 